\title{
The policy of tolerance in Uzbekistan (in the case of Greeks)
}

\author{
Abdurahmanova Jummagul Nomazovna ${ }^{1}$ \\ ${ }^{1}$ Doctor of Philosofy Chirchik state pedagogical institutue in Tashkent region, Uzbekistan \\ Email:j.abdurahmanova@cspi.uz
}

\begin{abstract}
This article describes the reasons why Greek national minorities were moved to Uzbekistan. In addition, because of the generosity, care and humanity of centuries-old values of Uzbek people, the Greek have found their place in other country. Including more than 130 nationalities living in the country due to the wise policy pursued in Uzbekistan today.
\end{abstract}

Keywords: multinational, national tolerance, national peace, international peace, religious confessions, Greeks, migrants, fewer nations, national cultural centres, ethnos, nations.

\section{INTRODUCTION}

In the territory of Uzbekistan ancient people have lived in the name of nationality and ethnicity. Successful development of any multinational country depends on stability, economic and political foundations and ethnical considerations in many respects dependent on peace and religious denominations in the country. Inter-ethnic and inter-ethnic tolerance in multinational countries is one of the most important factors in shaping national security.

World experience shows unilateral approach to interethnic relations leads to serious political problems in the country. In particular, the relationship between the nation that has been named by the state and other nationalities living in the country requires considerable attention. Otherwise, peace and stability in the community can be reined.

Interethnic harmony and tolerance are universal values. The principles of interethnic harmony and tolerance in a country where the representatives of different nationalities live are the determination of national development and serve as a guarantee of peace and stability.

The Republic of Uzbekistan one of the multinational country. Along with Uzbeks, people of different nationalities live in our country, with their culture, customs and traditions. The absence of national disagreement among the representatives of different nationalities and ethnicities living in Uzbekistan for centuries shows the eternal tolerance of our people. Patience and tolerance have long been the natural norms necessary for survival and development in our territory.

One of the main factors in the peaceful coexistence of the people of the country since the ancient times on the territory of our country is the tolerance of the Uzbek people. Tolerance is an integral part of the spirituality and culture of the Uzbek people. Humanity and tolerance of the Uzbek people which have been manifested in the hardest years of their relations with the few ethnic groups living in our country. In Uzbekistan, interethnic harmony persists, according to national or religious criteria.

One of the more than 130 ethnic groups living in our country is the Grecian nation with ancient history. Our people once again demonstrated their generosity and humanity to the Greeks who moved to Uzbekistan as political migrants in the post-World War II.

Greek nationality relocation looks at the history of the territory of Uzbekistan, representatives of the civil war that began in Greece after the Second World War ended with the victory of the royal monarchy and monarchy supporters. As a result, pro-democratic forces in the country are persecuted. People who are forced to leave their homeland and seek refuge in neighboring countries were forced to find shelter. The rest of the former Soviet country of origin is part of Greece in 1949, moved to Uzbekistan. Greeks moved to this year's 12 million people ${ }^{[1]}$. Persecution in his homeland, the land of hardship these people to remain living in this country to work, learn, learn to read because of the 
immediate humanitarian concern and generosity of the local people to access. As a result, the Greeks found plants and factories to work, as well as shelter. Although the people in the post-war migrants experiencing heavy periods, however, it is their sincere support and assistance grants. Download mentioned funds, awareness training, professional and possess a variety of courses were also organized. Sources show that in the 1954-1955 academic year, 600 Greek children graduated from 7 grades, and 65 had graduated from the 10 th grade $^{[2]}$. The number of Greek-speaking students has increased year by year. Moreover, they have not only continued their education in secondary specialized schools, colleges and universities. By the year 1975, 986 students who graduated from the existing evening schools in the Republic were representatives of the Greek nationality ${ }^{[3]}$. About $95 \%$ of these graduates continue their education in a number of high school and specialized secondary schools.

Greeks considered political refugees residing in Uzbekistan, they live in this country, got used to the social life, in their efforts to find jobs, to participate in the national economy due to their generosity, humaneness of the Uzbek people. Because, one of the most difficult years of Soviet domination of Eastern spirituality, following the best traditions of the best qualities of our people has shown.

During the years of independence, the country implemented sustainable policies due to inter-ethnic relations improved. A new stage in the development of inter-ethnic relations. Tolerance and large-scale works are carried out in the field. Reforms aimed at ensuring religious freedom and harmony between the two nations as a result of 16 religious faiths, more than 130 nations and nationalities live in peace and friendly. The representatives of every nation in our own national cultural centers in their own national traditions, customs preservation, development, further development of an independent homeland for the sake of creative work, initiatives and efforts are being supported by the government. Currently, there are 140 national cultural centers. This cultural centers in the city of Tashkent Greek Culture Society is also operating in the country. At present, about 10 thousand Greek diasporas also find their place in society, and representatives of other nationalities, as well as in all spheres and sectors of selfless service, his contribution to the development of society. They highly appreciated the prosperity of the motherland.

To date, several national cultural centers have been awarded state awards and awarded with 14 titles, and awards and medals, with the title of "Hero of Uzbekistan".

Uzbekistan has always been distinguished by the spirit of multinationality and multi-ethnicity in the spirit of interethnic respect and harmony. Special attention is paid not only to socio-economic and political spheres, but also to the strengthening of friendship between different nations and ethnicities living in our land, to the principles of religious tolerance. One of the peculiarities of stability in the republic is that all ethnic groups living in the Uzbek land are striving for understanding and harmony.

Today, the state policy aimed at ensuring inter-ethnic and inter-religious accord, solidarity and tolerance in the Republic of Uzbekistan has risen to a new level. It is also reflected in reforms in all spheres of Uzbekistan. In particular, the Decree of the President of the Republic of Uzbekistan of May 19, 2017 "On Measures for Further Improvement of Relations with International Relations and Relations with Foreign Countries", adopted by the "Strategy for Action in the Five Priorities of Development of the Republic of Uzbekistan in 2017-2021"[4], and on September 19, 2017, at the 72nd session of the United Nations General Assembly, a special resolution entitled "Enlightenment and Religious Tolerance" has attracted attention of the world community. These documents are of particular importance as ensuring the right of everyone to education, helping to eliminate illiteracy and ignorance, and most importantly, to promote tolerance and mutual respect, and to ensure religious freedom.

\section{CONCLUSION}

In conclusion it should be said that the world-wide work done in this process is an example of the high attention paid by the President and the Government to the universal tasks set out in the international documents, as well as the preservation of national traditions and customs of the people living in the country, their national traditions and customs, national and religious tolerance, ensuring harmony is to build a multi-ethnic united family feeling in the minds of everyone in Uzbekistan. 


\section{REFERENCES}

1. Central State Archive of the Republic of Uzbekistan, R-837 Fund, 42 List, 52 Collection Volume, Sheet 2.

2. According to the data of the Greek Cultural Association of Tashkent.

3. Decree of the President of the Republic of Uzbekistan "On strategy of further development of the Republic of Uzbekistan". February 7, 2017

4. Decree of the President of the Republic of Uzbekistan "On Measures to Further Improve Relations of Inter-ethnic Relations and Foreign Countries". // The People's Word. May 23, 2017. 